\title{
Contemporary built environment in the context of evolution of energy-efficient solutions in architecture
}

\author{
Stanisława Wehle-Strzelecka* \\ Kielce University of Technology, Faculty of Civil Engineering and Architecture, \\ Tysiąclecia Państwa Polskiego 7, 25-314 Kielce, Poland
}

\begin{abstract}
The article is concerned with the subject of energy consumption in construction; it also discusses problems related to creation of sustainable built environment and its links to the natural environment, with special emphasis placed on its links to climate.

Selected contemporary European development directions and trends in solutions using solar energy in buildings have been discussed in the paper, as well as various projects, concepts and realisations, mostly related to residential development.

The collected examples present the experiences of previous eras as well as their continuation contemporary realisations based on the possibilities of using innovative technologies in architecture within the framework of actions undertaken in European countries. They are to be found in various scales referring to whole districts, housing estates and housing complexes as well as individual buildings. They refer both to new development and to transformations of the existing infrastructure in the process of its restoration.
\end{abstract}

\section{Introduction}

The principles of rational and cost-effective management of energy implemented in shaping of the contemporary built environment are based on century-long experience. They follow excellent patterns of construction which have been emerging in various regions of the world over centuries. They came long before "the green revolution" and paved the way for the concept of eco-friendly building and now for sustainable construction.

The work here is the result of the author's analysis of energy-related concepts suggested in contemporary architectural and urban planning solutions. It discusses examples of energyefficient architectural solutions which have been adapted to harvesting renewable solar energy. The presentation includes both individual buildings and residential development complexes, estates and districts, as well as the solar cities that have been built in the last two decades in Denmark, Sweden, Austria, Germany and Holland. We can mention here among others the residential complexes in Sweden: Bo 01 "City of Tomorrow", Toarp in Malmö and Hammarby Sjöstad in Stockholm. In Denmark, the research focused among others on the Egebjerggård estate in Ballerup and the energy-efficient restoration of the existing

\footnotetext{
*Corresponding author: wehle@o2.pl
} 
development in Gothåbsvej and Helgesvej streets in Copenhagen. The study in Berlin included several energy-efficient housing complexes: Am Grünewald and Am Petersberg in Zehlendorf, an eco-friendly estate in the Pankow district, as well as the projects executed by IBA. The Vauban and Schlierberg districts in Freiburg have also been an important research areas. In Holland, the study focused among others on the Ecolonia - Alphen aan den Rijn estate, the EVA Lanxmeer eco-district in Culemborg and Nieuwland inAmersfoort. The analysis of Austrian experiences included housing complexes realised in Graz: in Rettenbacherstrasse, Andritzer Reichstrasse, Peterstalstrasse, Bergstrasse and Nordberggasse, and in Vienna: the Aspern an der Sonne estate, the Brünnerstrasse and Hofjägerstrasse complex and the multi-family complex in Roschégasse, Schellenseegasse and Schulerstrasse, as well as the building in Sagedergasse. The research also covered the sustainable residential district Linz - Pichling ( Solar City). A detailed analysis of the solutions has been presented in the author's work [1][2].
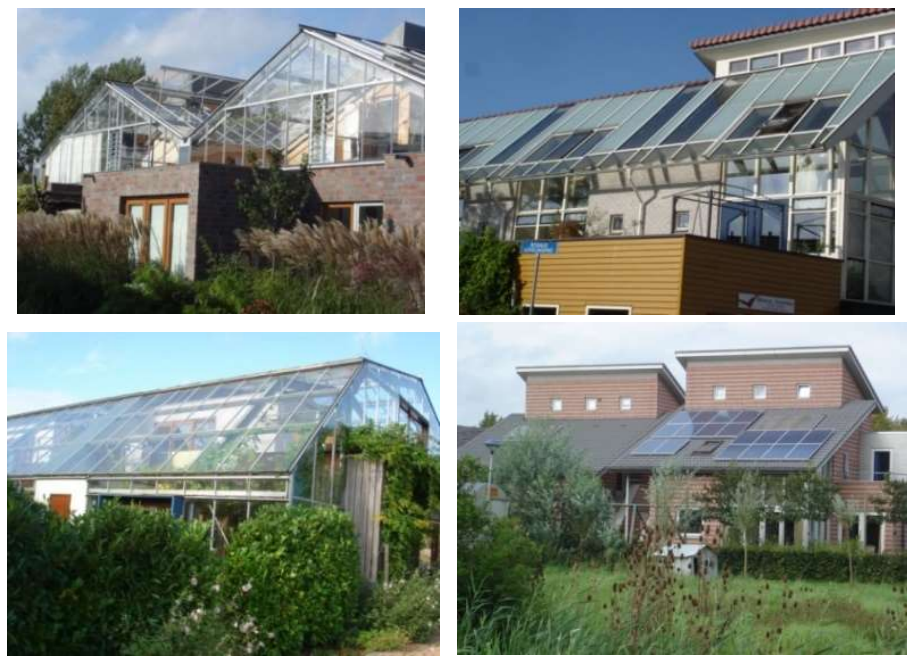

Fig. 1.Culemborg - eco-district EVA Lanxmeer („Sustainable Implant”, 1994-2009)energy-saving solutions with passive and active solar systems. Photo by author

Analysis of designs and realisations allows us to assume that the knowledge of how the idea of using solutions capturing the energy of the sun has been evolving throughout centuries significantly contributes to the understanding of contemporary energy-efficient solutions, and the experience of the time passed finds continuation in these solutions. Therefore, a considerable part of the article has been devoted to presenting the evolution of this concept andbringing back the centuries-long European tradition in this field of construction.
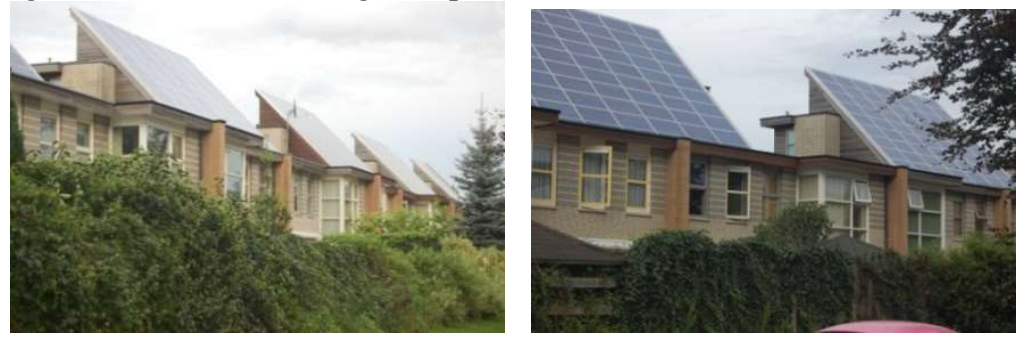

Fig. 2. Amersfoort, eco-district Nieuwland -energy-saving solutions with passive and active solar systems. Photo by author 
In general, we may assume that the period from antiquity to the mid- $20^{\text {th }}$ century created the foundations for using the greenhouse effect in contemporary construction in various forms of passive solar energy use. It also brought the first technologies of active systems and defined the basic principles of solar urban planning.

\section{Evolution of energy-efficient solutions in architecture}

The fact that solar energy was used in ancient European cities is evidenced by their urban structure (see e.g. the Greek cities of Priene, Olint or Delos, in which all buildings were granted the right of access to the sun). Using this renewable energy source was also promoted by applying simple and energy-efficient building methods (see e.g. the structure of the Socrates' house).

The legacy of ancient Rome also includes its contribution to the technological progress, which was the manufacture of glass and its application to cover window openings. At that time, glass components of buildings began to play the role of active planes serving the purpose of harvesting solar energy on the passive basis, which testified that Romans had mastered the skill of using the greenhouse effect to heat their interiors. Another great achievement was also employing glass in constructing conservatories, greenhouses and winter gardens. Evolution of these structures over centuries has enabled the contemporary and now common introduction of glazed verandas in eco-friendly and sustainable housing complexes.

Application of energy efficient principles in creating urban spaces manifested itself in the atrial-peristyle system of residential developments, as well as in the layout of residential interiors, with the introduction of climate buffer zones and intentional application of building materials of high thermal capacity. We may also agree that the legacy of the Roman culture includes laying down the law regulating access of buildings to the sun and the timeless principles of erecting buildings in relation to their location and climate collected in the works of Vitruvius [3].

The ideas of energy-efficient solutions, developed in antiquity, have been continued in Europe in various forms since the Renaissance. An example of the above may be the concept of villa Rotonda designed by A. Palladio, with its compact plan focused around the main central interior. Winter gardens and greenhouses in particular, as well as hothouses and conservatories with solid northern walls and large windows facing south, became the field of experiments (the $17^{\text {th }}$ and $18^{\text {th }}$ century) aimed at implementation of innovative structural and material-related concepts. They were related to new technologies of glass manufacture and the research into solar heat conduction (inter alia: H. de Saussure, the evidence of "the greenhouse effect," 1767).The form and structure of these buildings required application of adequate heating and ventilation, and the shape, size and inclination angle of the glazed southern planes were determined empirically with the view of getting the maximum of sun rays (F. Miller, 1751, H. Boerhave).[4, p.12] The systems of double glazing also emerged at that time. $\left[5\right.$, p.47] It should be added that the $18^{\text {th }}$ century, which started the industrial age, was called the Age of the Greenhouse due to its particular interest in using the passive principles of harvesting solar energy.

New structural possibilities and technologies enabled the emergence - in the $19^{\text {th }}$ century, considered the second age of glass, with Gothic being the first - of various buildings using solar energy on the passive principle. These would encompass both small winter gardens of various forms attached to houses and representational monumental palm- and other hothouses (designs by J. Paxton with his famous Crystal Palace in London built 1851, among others). Greenhouses of simple form and structure adjusted to the cultivation technology were very popular. 


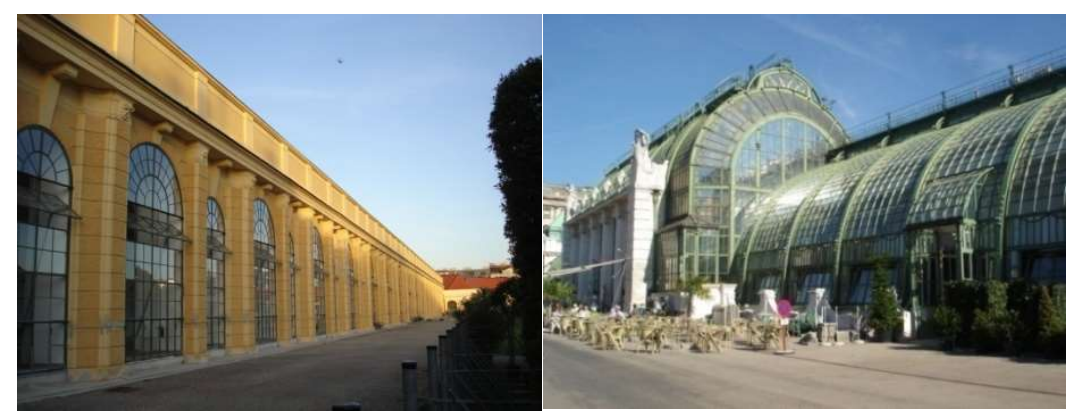

Fig.3. a-orangery at the Schönbrunn Palace, Vienna(arch. N. Pacassi. 1754), b- Palm House in Vienna (arch. F. Ohman, 1905). Photo by author

A significant role in the development of architectural forms using the energy of the sun was played at that time by the concept of winter gardens that were integrated with the house(arch. H. Repton, England). Similarly to the residential developments of our time, these glazed, south-oriented structures were incorporated into ground floors of buildings, into higher storeys or placed on the roof. They were also designed in the form of glass corners or structures connecting various levels of a building. They occurred in a plethora of aesthetic forms created using diverse structural materials (steel, wood) and in diverse shapes (rectangular, polygonal or circular).

The $19^{\text {th }}$ century also brought the concepts of energy efficient urban developments, oriented towards the south and adjusted to using solar energy based on the passive principle (B.C. Faust - the model of an ideal city, 1824, the Palotsa housing estate in Hungary, arch. L. von Zanth, and in England e.g. Akroydon 1855, New Lanark) [6, p.34]. The simple rules applied in them included opening residential interiors towards the south and minimizing apertures in northern walls.

The innovative character and great variety of energy-efficient solutions, including in particular the winter gardens created in the period between the 16th and 19th centuries as well as in the first half of the 20th century, following the concept of modernist housing estates, found continuation in material-related solutions and structures of contemporary passive systems, adapted to direct or indirect harvesting of solar energy for the purposes of heating interiors in buildings.

The experiences and experiments of previous centuries have also enabled a number of technological achievements that have paved the way for the development of active solar systems in the construction industry of the $20^{\text {th }}$ century. Some of them, like using solar mirrors or research into the greenhouse effect $(\mathrm{H}$. de Saussure, J. Herschel, S. P. Langley, E. S. Morse), contributed to the emergence of prototype solar collectors already at the end of the $19^{\text {th }}$ century, and later to other solar installations used in construction. On the other hand, the works by A. Volt and A. Becquerel gave rise to the development of photovoltaics, which now includes heliostats installations, related to construction, emerging in various scales from micro-installations to photovoltaic farms and solar power plants, which are considered to be the future of solar energy generation.

\section{Contemporary trends in creating developments using the energy of the sun}

The concepts of using solar energy in architecture discussed above, developed from antiquity until the late $80 \mathrm{~s}$ of the $20^{\text {th }}$ century, may be classified as the first generation of solutions which paved the way for the present options, developed for approximately two decades and 
classified as the second generation based on the now available innovative technologies. The second generation was preceded in the $20^{\text {th }}$ century by two periods (waves) of interest in using solar energy in construction, which occurred both in Europe and in the USA.The climate zones in Europe and the USA correspond to each other ( New York is situated at the latitude of Naples).Work on solutions based on passive solar systems was continued in these periods, and in the second half of the $20^{\text {th }}$ century, various concepts of combining them with active systems were first promoted. The classification of solutions and assigning them to specific generations has been based on the author's study and on the work by Z. Śliwiński [7, p. 600]. The author's research has been presented in monographs [1] and [2].

An important role in application of energy-efficient solutions (the first wave of sun architecture) was played in the first half of the $20^{\text {th }}$ century by the ideas of organic architecture and of modernism. They were implemented within two opposing concepts of urban planning: the garden-city (T. Garnier and A. Rey, E. Howard, W. Atkinson, among others) and the functional city (e.g. Le Corbusier). Modernism promoted functional, cost-efficient, energyefficient and simple solutions in housing environment creation. Opening buildings to sunlight was considered the fundamental design principle. The solutions to achieve this purpose included the models of heliotropic "ruler-like" residential development (J. J. P. Oud, A. Loos, E. May, B. Taut and M. Wagner, P. Behrens, W. Gropius) as well as introduction of winter gardens and natural green shading screens (L. Migge, H. Muthesius, W. Moltke). The solutions demonstrated new possibilities in the field of building materials and construction techniques and reflected the particular fascination of architects with glass (the new third age of glass). They have retained their appeal until today and they have left clearly discernible traces in many designs of energy-efficient, environmentally friendly and sustainable housing estates realised in Europe in the last two decades.

European projects realised in the first half of the $20^{\text {th }}$ century were linked to the American experiences in developing passive technologies of using sun energy. It was particularly evident in comprehensive designs of sun houses, forms of southern façades and walls of high thermal capacity, systems of natural ventilation and shading (A. Brown, G. F. Keck, R. Neutra, among others, and later on - Ch. Alexander). Architects were also experimenting with various shapes and plans of buildings in the aspect of energy efficiency and interiors that would be penetrated to a large degree by sun rays in winter.

The search for a model of a glass sun house, adapted to the climate, resulted in the emergence of concepts of prefabricated sun houses (for example the crystal house, Keck \&Keck, autonomous "4D” house - Dymaxion House, R. B. Fuller). The achievements are now being continued in the concepts of modern, energy-efficient buildings with transparent envelopes (glass "skin"). They are realised in various scales, from small buildings to largeformat transparent structures (examples: Biosphere 2 in Oracle in Arizona, with the area of $12,700 \mathrm{~m} 2$, Eden Project in St. Austell in Cornwall designed by N. Grimshaw \&Partners, England 2001, Mont-Cenis Academy in Herne-Sodingen designed by Jourda et Perraudin, 1992, Federal Environment Agency in Dessau designed by Sauerbruch Hutton, 1998 2005). They were continuation of engineering structures of R. B. Fuller (the dome in Montreal and over Manhattan), which were cost-efficient regarding materials and energy. The listed facilities are to be classified as ground-breaking engineering realisations of contemporary technology-oriented architecture, implementing the high-tech and eco-tech concepts. 


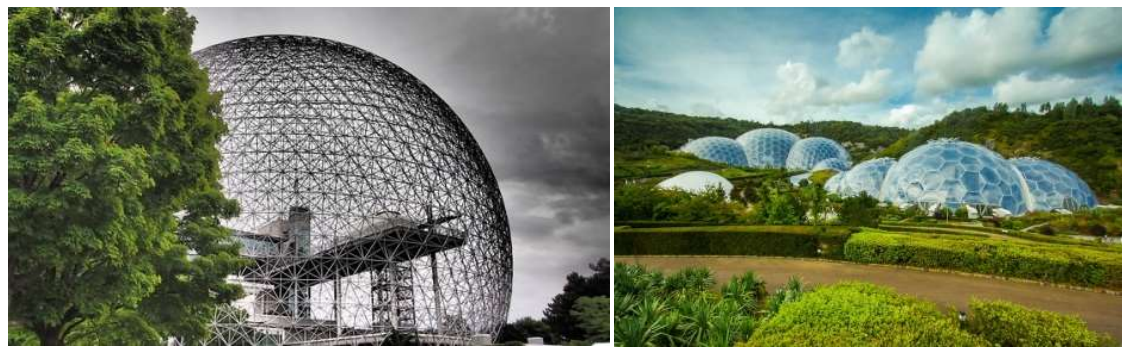

Fig. 4. a- The Montreal Biosphère, formerly the American Pavilion of Expo 67, by R. B. Fuller, b-Eden Project in St. Austell in Cornwall (arch. N. Grimshaw\&Partners,2001)

Concepts of energy-efficient residential buildings also continue to draw from American experiments conducted at M.I.T. $(1938-62)$, which were aimed to test options of using the sun energy to heat houses in colder climates.

Another important contribution to the development of the present-day solutions was made by F. L. Wright's organic houses (the house designed for H. and C. Jacobs, Middleton in Wisconsin, among others) or the designs of R. Neutra (the philosophy of bioarchitecture) as well as P. Soleri's concepts of urban mega-structures that would be self-sufficient in terms of energy and capable of harvesting sun energy, which is consistent with the currently implemented ideas of city ecology.

The age of economy and the age of the machine ended in the 70 s of the previous century. There appeared a possibility to initiate a new pro-ecological culture, and the eco-friendly and eco-energy trend in construction enjoyed its renaissance. The interest in energy-efficient solutions (the experimental period in Europe and in the USA) was the reaction to the worldwide energy crisis, but also the result of the growing awareness among the general public that a new paradigm in culture must be found. This new paradigm was the concept of ecogrowth (Stockholm Declaration with the slogan: We only have one Earth, 1972).

The search for solutions in architecture at that time split into two trends. The first one proposed further development of the hitherto applied passive systems (direct and indirect) and bioclimatic solutions (e.g. American creators: Trombe, S. Baer, D. Watson, D. Wright, W. Kebaugh, P. Davis, B. Lumpkins and S. Nichols, D. Holloway, A. Predock).Other solutions were also applied, such as insulated, combined or hybrid systems, as well as various types of individually designed southern collector walls. Emphasis was put on their functionality, cost effectiveness, logic and beauty, especially when compared with conventional solutions. The pioneering European solutions, consistent with the low-tech philosophy, also appeared at that time. They were simple in their structure, with forms fitting harmoniously into the landscape, climate and tradition, and without costly installations or photovoltaic systems (e.g. J. Eble, P. Hübner, R. Erskin, B. Varne, Vandkusten studio).An exemplary model was, among others, the Natur Huset in Stockholm (B. Warne, 1978), with its glazed structures playing the role of solar energy collector. The above principles are still being continued in contemporary architecture.

The other trend sought to combine passive and active systems (the Autarkic House, A. Pike, 1971-79, R. F. Augustine, M. Jantzen and T. Bakewell). It is currently continued in numerous realisations of self-sufficient and energy-plus buildings erected in compliance with sustainable construction. A great achievement of the 70s was inter alia the building for company W. Faber \& Dumas in Ipswich in England (designed by N. Foster and Partners, 1971-75), which implemented in reality the glass wall concept designed by M. van der Rohe in 1922.

The 80 s brought the concept of the "energetically active" wall harvesting solar energy (Mike Davis, 1981, dynamic skin, polyvalent wall), as well as the first attempts to integrate photovoltaic modules with buildings. The housing complex designed by Herzog + Partner in 
Munich in 1982 is considered to be the first development of this type. [8, p.112] The Berlin experiences of IBA (1979-1987) also played an important role, and they found a permanent place in the tradition of "green" architecture, creating new trends in actions aimed at sustainable construction.

It was also in this period that the concept of using solar energy started to be combined with other cost-effective and eco-friendly solutions, such as, among others, waste composting, rainwater collection and use, heat recovery as well as building structures partially or completely buried in the ground (D. Wright, M. Wells, J. Turrell, H. Hollein).

The achievements of the discussed period are still relevant today and their continuation is visible in numerous energy-efficient, eco-friendly and sustainable housing estates erected in Europe in the last two decades as part of the trend to create diverse sustainable relations between the natural and built environments adapted to the concept of sustainable growth (Rio de Janeiro Declaration with the slogan Environment and Development, 1992) based on balancing the ecological, economic and social factors.

Designs implementing the above concept and its accompanying legislation may be classified as the second generation of energy-efficient solutions using the energy of the sun. The first generation encompasses solutions developed from antiquity to the $70 \mathrm{~s}$ of the $20^{\text {th }}$ century. Subsequent years saw the emergence of experimental solutions which provided foundations for the new technological achievements developed at present as the second generation. It may be assumed that the first signal of this new generation were the solutions implemented in the period of experiments with Solar IV - the fourth house built at M.I.T. (Lexington, Ma., 1958) in the USA.

At present the second generation is represented by very numerous energy-efficient houses, housing estates and European solar cities, among others: Solar Stadt Linz-Pichling in Austria, districts in Vauban and Schlierberg in Freiburg, Germany, Ecolonia, Almere, Heerhugowaard, Amersfoort and Culemborg in Holland, a housing estate in MalmöBo 01 “ City of Tomorrow," and eco-district Hammarby Sjöstad in Stockholm, Sweden, a prototype housing estate in Mallorca, a district model in Shanghai designed by arch. R. Roberts Partnership (1994), a complex of buildings in the Daimler-Chrysler centre at Potsdamer Platz designed by R. Piano, or the first-in-the-world eco-city Masdar City (2006).
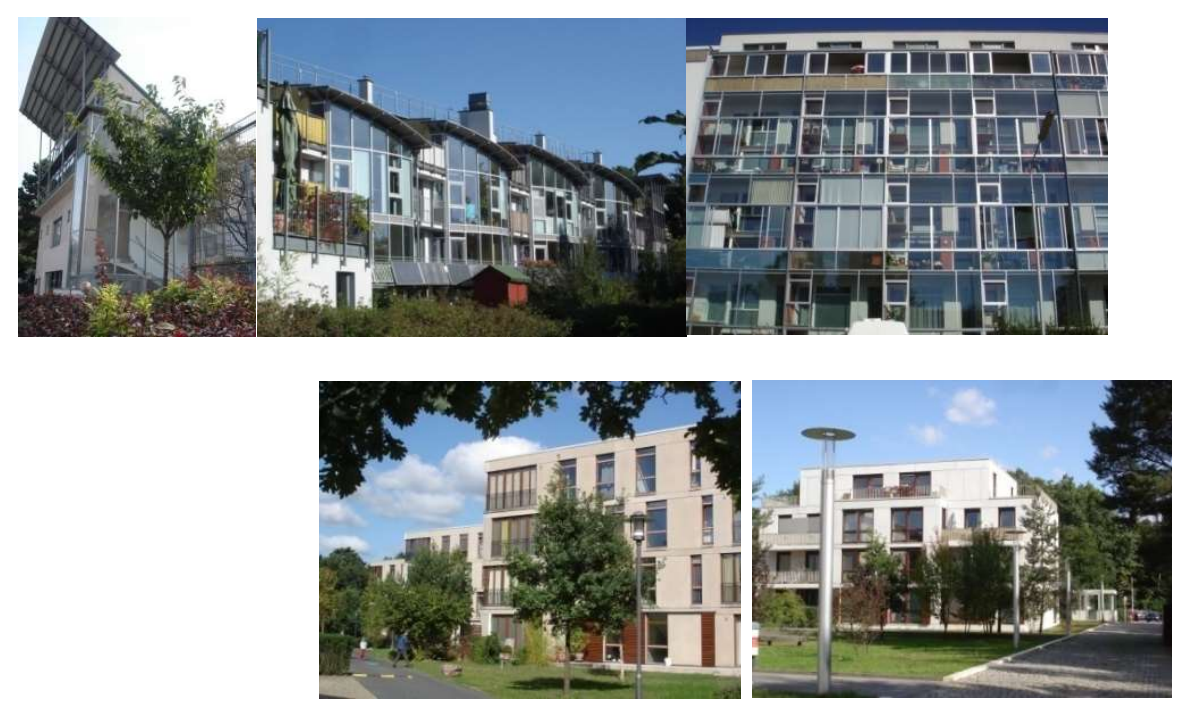


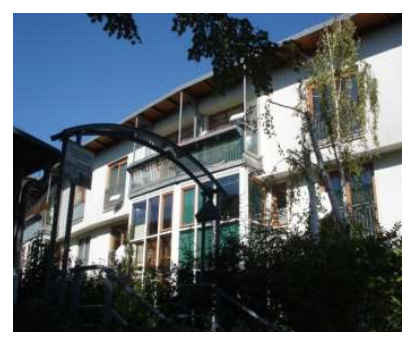

Fig. 5.Southern elevations of energy-efficient residential buildings at theSagedergasse(Houseperiscope),Hofjägerstrasse, Roschegasse and Brünnerstrasse in Vienna and in Berlin: Am Grünewald and Am Petersberg in Zehlendorf, Berlin. Photo by author

A special achievement is the headquarters of Lloyd in London (designed by R. Rogers + Architects, 1995 -2000). It is considered to be implementation of the mur neutralisant idea invented by Le Corbusier. The latest European architectural realizations were presented, among others, in the publication: [10, p.18], [11, p.32], [12,p.26 ], [13, p.38]. The second generation also includes individual buildings and complexes which are subject of the author's research mentioned in the introduction to this paper. The research has been presented in authors publication [14] [15]. Compare also [16],[17].A model example, among them, of how the modern living environment of the 21 st century should be created, due to its modern infrastructure and technologies, is considered the Pichling district in Linz (the Solar City).The aim was to create a large sustainable urban cluster of a humanistic pattern, taking into account the residents' comfort and nature (a cost efficient model, among others in the aspect of energy or water consumption) [2,p.178].
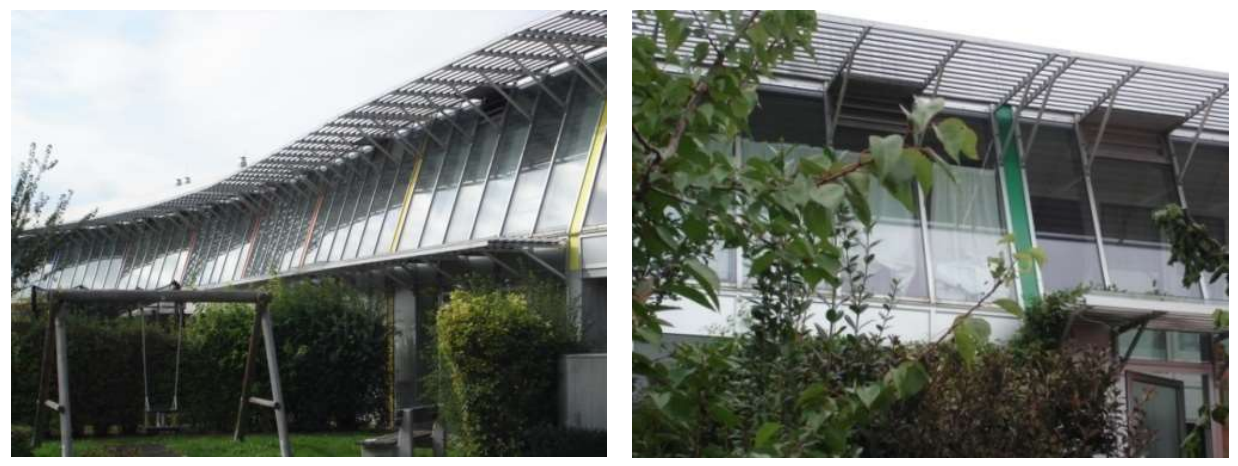

Fig. 6. Southern elevation of energy-efficient residential buildings with winter Gardens, Pichling district in Linz (the Solar City). Photo by author

\section{Conclusions}

Contemporary energy-efficient solutions in construction, adapted to harvesting solar energy and consistent with the actions aimed at creation of sustainable built environment stem entirely from a century-long tradition. At the same time, they may be considered the desired model of architecture for the future, which should be characterised by coherence with natural environment, particularly with the climate.

Analysis of examples and observation of contemporary trends in creation of sustainable built environment leads to the conclusion that the present time is characterised by a diversity of cost-efficient solutions, in terms of energy, materials and use of space, implemented with a selected choice of materials and technologies. Actions are undertaken in different scales, 
from individual helioactive buildings to large urban projects (solar cities), together with buildings that are buried in the ground. Futuristic visions also deserve some attention.

At present, the countries of the European Union value highly the legacy of inter aliaScandinavian countries, Germany, Holland, Austria and the United Kingdom.Scandinavian countries and then Germany (the concept of low-energy and passive house: the project in Darmstadt - Kranichstein, 1991), France and Switzerland have set up the most ambitious and far-reaching regulations in Europe.It encompasses erection of energyefficient, zero-energy or energy-plus projects, estates and whole city districts. Solutions based on using solar energy in the passive and active way (collector systems, photovoltaics) are being continuously improved and changed in the process of research, experiments and pilot realisations.

Energy-related concepts vary from High-, through Eco-, to Low-Tech and No-Tech solutions. The last three types of simple solutions are promoted since they are not advanced in terms of technology, but, instead, based on traditional patterns, typical of passive systems, of using the greenhouse effect combined with the carefully selected form (form follows energy) and innovative structural and material-related solutions. The whole building or its individual components, together with their geometry, are used as the heat collector and container.The following helioactive components of the building serve this purpose (among others): solar and collector-accumulation walls, transparent insulation, solar windows, climate buffer zones (winter gardens of the latest generation, energy holes). It is evidenced by the extraordinary boom in glass architecture in the last two decades. Another feature is introduction of the principles of interior zoning, known for its long tradition, and adjusting developments to land configuration.

Active solar systems, combined with passive ones, in the second generation of solar architecture, constitute complementation of energy-efficient standards.

Contemporary actions aimed to promote energy-efficient solutions in construction are consistent with the general requirements laid down for the whole sustainable built environment. They are defined by subsequent generations of quality assessment tools continuously developed in Europe and the USA.

The future of these solutions is to be seen in the introduction of innovative materials, including helioactive ones, which would have the capacity of sunlight transformation and interior shading on the basis of the achievements of physics, biology and bionics (smart materials, among others). The ultimate aim is to obtain the structure and thermo-insulating smart coatings of buildings (building skins) that would be capable of reacting, according to the needs of residents, to the changing climate conditions in the surroundings (insolation, temperature changes, light, wind), following the capabilities of living organisms.

\section{References}

1. S. Wehle-Strzelecka, Architektura słoneczna w zrównoważonym środowiskumieszkaniowym, Monografia 312, seria Architektura, Kraków (2004)

2. S. Wehle-Strzelecka, Energia słońca $w$ kształtowaniu środowiska mieszkaniowego ewolucja koncepcji na przestrzeni wieków, Kraków (2014)

3. Witruwiusz, O architekturze ksiag dziesięć, Warszawa (1999)

4. U. Timm, Wohnräume unter Glass. Der Wintergarten, Callwey, Monachium (1987)

5. K. Butti, J. Perlin, Golden Thread,2500 years of solar architecture and technology, New York(1980)

6. J.C.K. Kirchenmann, Ch.Muschalek, Quartiere zum Wohnen, Stuttgart (1977)

7. Z. Śliwiński, Eine Chronologie der Solararchitektur in den USA, Detail,6(2005) 
8. M. Hegger, M. Fuchs, T. Stark, M. Zeumer, Energy Manual. Sustainable Architecture, Birkhäuser, Basel, Boston, Berlin (2008)

9. D. Gauzin-Müller, Sustainable Architecture and Urbanism. Concepts, Technologies,Examples,Basel, Berlin, Boston(2002)

10. A. Mayer, D.Gerber, U. Sturm, P. Schwehr, Verdichtetes Wohnen mit Einfamilienhausqualitäten, Detail Green, 01/13 ( 2013)

11. Wohnquatier in Brüssel, Detail Green, 01/13( 2013)

12. Sozialer Wohnungsbau in Luxemburg, Detail Green, 02/16 ( 2016)

13. Genossenschaftliches Wohnquartier in Zürich, Detail Green, 02/16 (2016)

14. S. Wehle-Strzelecka, Close-to nature housing- Austrian examples, Monograph: Contemporary problems in architecture and urbanism, vol.IV, Kraków (2014)

15. S. Wehle-Strzelecka, Architecture of winter gardens open to sunlight, Monograph: Light in Architecture, Housing Environment 20/2017, Kraków (2017)

16. K. Zielonko-Jung, Kształtowanie przestrzenne architektury ekologicznej w strukturze miasta, Warszawa(2013)

17. P.Markiewicz, Zintegrowane projektowanie energetyczne jednorodzinnych, energooszczędnych budynków mieszkalnych, Kraków (2017) 